\title{
DEVELOPMENT OF A METHOD FOR DESIGNING LEACHATE DESALINATION PROCESS USING LANDFILL CELL MODEL
}

\section{Kazuo Tameda *, Tong Li, Jiaxing Liu and Sotaro Higuchi}

Research Institute for Resource Recycling and Environmental Pollution Control, Fukuoka University, 10, Koyo-cho, Wakamatsu-ku, Kitakyushu, Fukuoka 808-0002, Japan

Article Info:
Received:
21 February 2019
Revised:
18 July 2019
Accepted:
29 July 2019
Available online:
26 September 2019
Keywords:
Landfill cell model
Leachate treatment plant
Cl$^{-}$
Open type
Closed type

\section{INTRODUCTION}

When designing leachate treatment plants in Japanese landfill sites, the capacity of such plants and the quality characteristics of raw leachate are the main examined parameters. There are two types of landfill in Japan: 1) conventional open landfill sites without a roof and 2) closed landfill sites with a roof. In the case of open type landfill sites (hereinafter referred to as "open type"), the capacity of leachate treatment plants has been researched during the last decade and a half based only on calculations using meteorological data. In the case of closed system landfill sites (hereinafter referred to as "closed type"), the same as for the open type, methods for capacity calculation during the past 15 years have used meteorological data or alternatively liquid:solid ratio in the range of 1-3 (liquid: solid ratio $>3$ in the case of desalination treatment) (Japan Waste Management Association, 2010). The characterization of raw leachate quality has had less of a robust scientific basis, especially the characterization of $\mathrm{Cl}^{-}$concentration. Instead, this has generally been based on existing practices at other operating leachate treatment plants (Japan Waste Management Association, 2010). However, regarding the amount of leachate and the raw leachate quality in actual landfill sites, a close relationship of these variables with $\mathrm{Cl}$ content and waste cell placement method can be found; furthermore, this relationship changes depending on the landfill method and dilution zone (no dumping area) or the amount of water.

In the conventional method of calculating the capacity of leachate treatment plants, the planned raw water quality can be characterized according to the landfill shape (the height of one landfill layer), dilution zone (no dumping area), waste cell placement method and leachate landfill property. By combining this with the Landfill Cell Model (Kazuo et al., 2016, 2017a, 2017b), it is possible to characterize the optimal leachate treatment plant capacity, balancing reservoir capacity and the expected concentration of $\mathrm{Cl}^{-}$in raw leachate for both open and closed types. Besides, the volume of water for sprinkling in the closed type can also be established, as described here.

\section{MATERIALS AND METHODS}

\subsection{Calculation methods}

2.1.1 Methods of calculating the peak concentration of $\mathrm{Cl}^{-}$ in leachate (Kazuo et al., 2016, 2017a, 2017b)

The peak concentration of $\mathrm{Cl}^{-}$can be predicted according to the following parameters: " $\mathrm{Cl}$ content in incin- 
eration residues," "peak concentration of $\mathrm{Cl}^{-}$in the height of one landfill layer," "dilution zone in landfill sites," and "landfill by stacking up." The predicted flow is shown in Figure 1. In this research, to estimate the peak concentration of $\mathrm{Cl}^{-}$, the Landfill Cell Model is used. As shown in Figure 2, Hi Hn was integrated in the $\mathrm{x}$-direction. $\mathrm{Vi} \sim \mathrm{Vn}$ was integrated in the y-direction. Di Dn was integrated in the z-direction. The assumed calculation steps are explained as below.

Step (1) The daily landfill capacity of the target landfill site is calculated and the capacity and size (length $\times$ width $x$ height) of the Landfill Cell Model are set (capacity per cell is about $10-30$ days).

Step (2) The numbers of cells in the $\mathrm{x}$-direction ( $\mathrm{Hi} \sim \mathrm{Hn})$, $y$-direction ( $\mathrm{Vi} \sim \mathrm{Vn})$, and z-direction (Di Dn) of the Landfill Cell Model are set to ensure the correct shape of landfill sites.

Step (3) The volume of water for sprinkling is set according to the daily precipitation of the Landfill Cell Model in the case of the open type or through the liquid: solid ratio in the case of the closed type.

Step (4) The peak concentration of $\mathrm{Cl}^{-}$is set by the $\mathrm{Cl}$ content in incineration residues from the landfilling target.

Step (5) A formula for predicting landfill cell peak concentration is produced from the $\mathrm{Cl}$ content in Step (4) and using the results of temporal changes in the leachate quality in the experiment on a simulated landfill layer, which is filled with incineration residues. At the branching point of the rate of reduction of $\mathrm{Cl}^{-}$concentration, it is divided into the initial stage, the intermediate stage, the end stage, and the stable stage of the landfill. The predictive formula is presented in Figure 3. Depending on the parameters, the

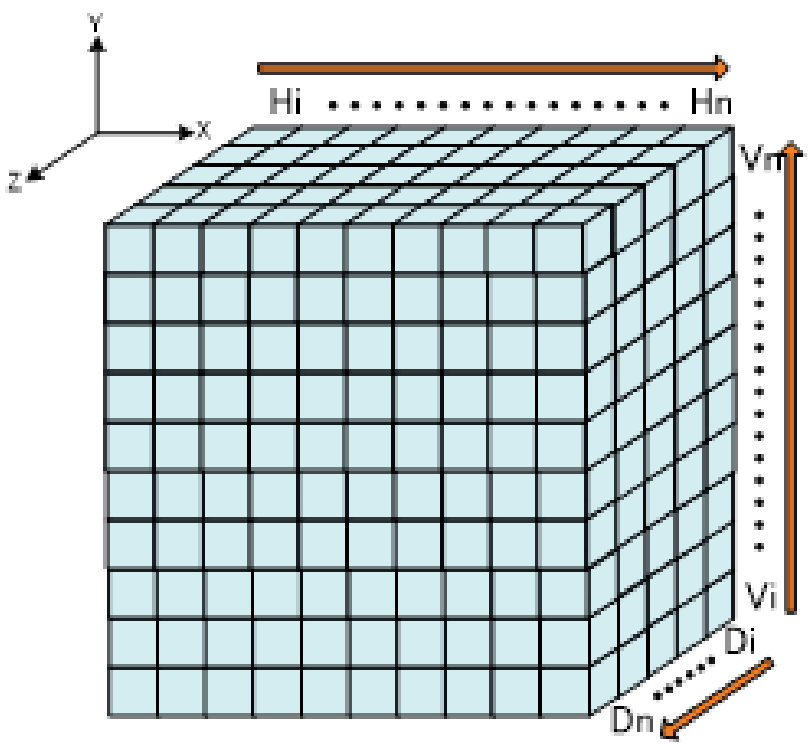

FIGURE 2: Landfill Cell Model.

predictive formula sometimes stays the same from the initial stage to the stable stage. In this study, we used the daily variation of $\mathrm{Cl}^{-}$in the leachate from the simulated landfill site filled with incineration residue (mixing ratio=main ash: fly ash=7:3) with a $\mathrm{Cl}$ content of $67 \mathrm{~g} / \mathrm{kg}$. The results show that the predictive formulas are $Y=-3.31 X+114,971$ in the early period, $Y=-0.52 X+31,553$ in the middle period, $Y=-0.041 X+7,003$ in the late period, and $Y=495$ in the stable period of landfill.

Step (6) The leaching properties upon increasing the landfill cell are characterized. Details of the leaching prop-



FIGURE 1: The setting flow of peak concentration of $\mathrm{Cl}^{-}$. 
erties of a cell stacked up on others are described later in "Leaching properties of one cell."

Step (7) The waste cell placement method is characterized by considering the timing of addition. (The x-direction indicates the landfill process and the $y$-direction expresses the timing of addition.)

Step (8) A calculation for predicting the $\mathrm{Cl}^{-}$concentration is performed according to the waste cell placement method in Step (7).

Step (9) The peak concentration of $\mathrm{Cl}^{-}$during the duration of existence of the landfill is estimated.

Step (10) A general judgment on the peak concentration of $\mathrm{Cl}^{-}$is made; then, one proceeds to Step (11) or back to Step (3) and Step (7) to perform the examination again. ized.

Step (11) The peak concentration of $\mathrm{Cl}^{-}$is character-

Reduction ratio of $\mathrm{Cl}^{-}$concentration in leachate penetration (Kazuo et al., 2017a)

1) Leachate concentration $a_{i}(\mathrm{mg} / \mathrm{L})$ on the number of days after landfill $n_{i}\left(\right.$ Day $\left.n_{i}\right)$ is obtained from Figure 4 using the daily precipitation (the volume of water for sprinkling) on Day $n_{i}(i=1,2,3,4 \ldots)$. Migration properties of leachate concentration $a_{i}(m g / L)$ of Day $n_{i}$ cell is calculated by multiplying migration rates and $a_{i}(m g / L)$. When a migration rate for the case $\left(V_{m}\right)$ in which Day $n_{i}$ cell is landfilled at the $m$-th cell from the basement is defined as $\mathrm{M}_{\mathrm{m}} \%$, the rate of migration $\left(M_{m}\right)$ from Day $n_{i}$ cell to the cell immediately below it is $100 \%$, and those to the second and subsequent cells below it are preset as $M_{m-1} \%, \ldots M_{3} \%, M_{2} \%, M_{1} \%$. (The migration rate is the ratio to the initial leachate quality relative to the initial leachate quality with $a_{i} \mathrm{mg} / \mathrm{L}$ that migrates to the cell below and is expressed as a percentage.) The migration rate $\mathrm{M}_{\mathrm{m}} \%$ is set based on the rate of decrease of the peak concentration about landfill by stacking up.

2) Leachate concentration at the m-th cell from the basement on Day $n_{i}$ is determined according to the location $\left(V_{m}\right)$ of Day $n_{i}$ cell in the $y$-direction.

The location $\left(V_{m}\right)$ of Day $n_{i}$ cell in the $y$-direction gives the following calculations:

Leachate concentration of all Day $n_{i}$ cells at the basement of the landfill site, $V_{1}$, is expressed by the following equation: $a_{i}(\mathrm{mg} / \mathrm{L}) \times 100 \%$,

where Day $n_{1}$ is the number of days required to landfill one cell, which was set at Step (1).

Migration of Day $n_{i}$ cell at $V_{m}$ starts $\left\{m \times n_{1}\right\}$ days after Day $n_{i}$, that is, at Day $N_{i}=n_{i}+\left\{m \times n_{1}\right\}$, and it ends at Day $N_{i}+n_{1} \times j(j=1,2,3,4 \ldots)$,

where $M_{1} \%$, the rate of migration to outside of the landfill site, of the Day $n_{i}$ cell is calculated until the initial leachate quality $M_{m}=100 \%$ completely migrates outside of the landfill site. In other words, calculation is performed until an equation $100 \%-\Sigma M_{1, k}<M_{1}$ holds, where the sum of the migration rates outside of the landfill site is $\Sigma M_{1, k}=\left(M_{1,1}+M_{1,2}+\ldots+M_{1, k}\right)(k=1,2,3$, 4...).
Therefore, the leachate concentration of Day $n_{i}$ cell on Day $\mathrm{N}_{\mathrm{i}}$ is expressed by the following equation: $\underline{\mathrm{a}}_{\mathrm{i}}(\mathrm{mg} / \mathrm{L})$ $\times \mathrm{M}_{1, \mathrm{k}} \%$.

Next, the leachate concentration of Day $n_{i}$ cell on Day $\mathrm{N}_{\mathrm{i}}+\mathrm{n}_{1} \times \mathrm{j}$ when the migration of the leachate concentration $a_{i}(m g / L)$ ends is expressed as follows: $a_{i}(m g / L) \times$ $\left(100-\Sigma M_{1, k}\right) \%$.

3) The calculation described above in 2) is performed for all cells in the landfill area in this Landfill Cell Model and the volume of water for sprinkling in the dilution zone is added to it at the end to obtain the total leachate concentration.

4) The following is an example of the calculation described above of the case where four cell layers are stacked up (Figures 5, 6).

Assume that:

- landfill is advanced from $\mathrm{V}_{1}$ to $\mathrm{V}_{4^{\prime}}$

- only the migration property from $\mathrm{V}_{4}$ is considered,

- the leachate concentration from $V_{4}$ is $a_{i} m g / L$ ( $i$ re-

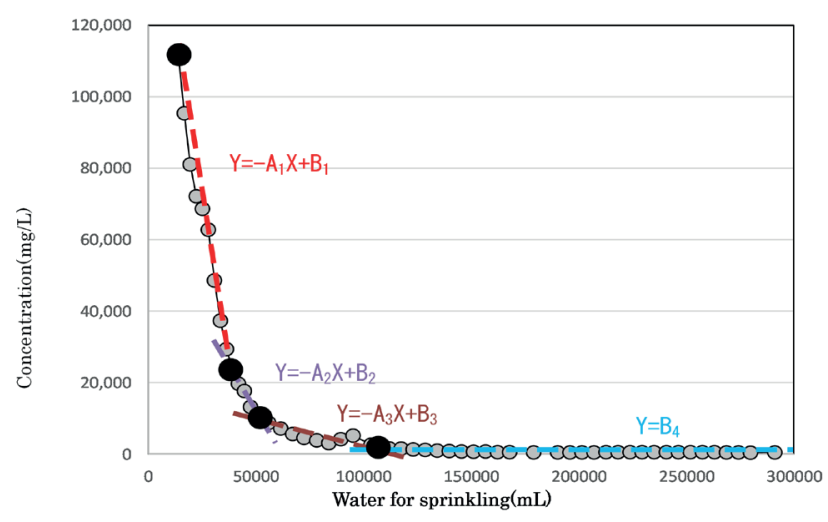

FIGURE 3: Conceptual diagram of formula for predicting landfill cell peak concentration

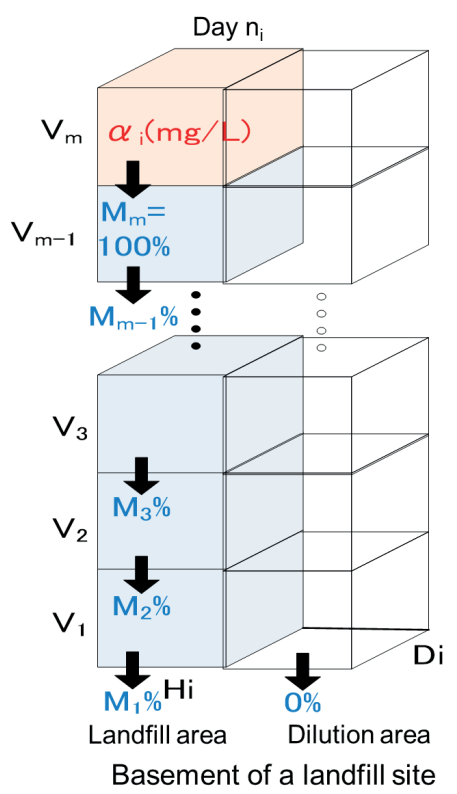

FIGURE 4: Conceptual diagram of the reduction ratio of $\mathrm{Cl}$ - during the landfill by stacking up. 


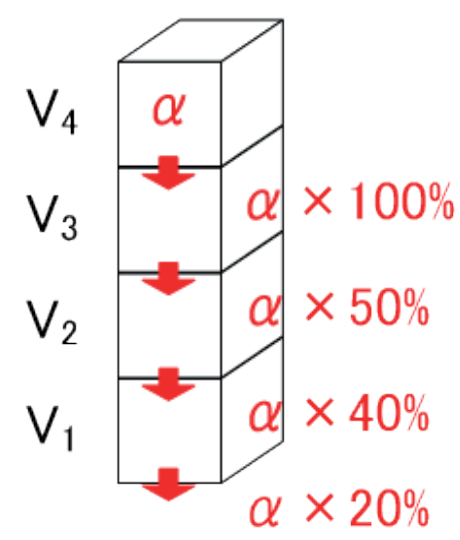

FIGURE 5: The reduction ratio of $\mathrm{Cl}^{-}$in the case where four cell layers are stacked up.

presents the number of days; $i=10,20,30, \ldots)$, and

- the migration rates from $\mathrm{V}_{4}$ in the $y$-direction: first layer, $100 \%$; second layer, 50\%; third layer, $40 \%$; and fourth layer, $20 \%$.

- 10 days after the landfill: The leachate quality $a_{10} \times$ 100 migrates from $V_{4}$ to $V_{3}$

- 20 days after the landfill: The leachate quality $a_{20} \times$ $100 \%$ migrates from $V_{4}$ to $V_{3}$ and the leachate quality $a_{10} \times 50 \%$ migrates from $V_{3}$ to $V_{2}$.

- 30 days after the landfill: The leachate quality $a_{30} \times$ $100 \%$ migrates from $V_{4}$ to $V_{3^{\prime}}$, the leachate quality $a_{10}$ $\times 60 \%$ migrates from $V_{3}$ to $V_{2}$, the leachate quality $a_{20} \times 50 \%$ migrates, the leachate quality $a_{10} \times 40 \%$ migrates from $\mathrm{V}_{2}$ to $\mathrm{V}_{1}$.

- 40 days after the landfill: The leachate quality $a_{40} \times$ $100 \%$ migrates from $V_{4}$ to $V_{3}$, the leachate quality $a_{20}$ $\times 50 \%$ migrates from $V_{3}$ to $V_{2}$, the leachate quality $a_{30} \times 50 \%$ migrates, the leachate quality $a_{10} \times 40 \%$ migrates from $\mathrm{V}_{2}$ to $\mathrm{V}_{1}$, the leachate quality $\mathrm{a}_{20} \times 40 \%$ migrates, and the leachate quality $a_{10} \times 20 \%$ migrates from $V_{1}$ to outside of the landfill site.

Conduct the subsequent calculations in the same way.

\subsubsection{The calculation method for characterizing the planned} raw water quality in open type (Kazuo et al., 2017b)

Figure 7 shows the flow for designing a leachate treatment plant (the capacity of the leachate treatment plant, the capacity of the adjustment dam, and the quality of planned raw water).
(1) The maximum and minimum capacities of both the leachate treatment plant and the adjustment dam are calculated from the average daily precipitation and monthly maximum precipitation in the last 15 years. (The possible amount of evaporation can be calculated by using the Blaney-Criddle method and the seepage coefficient $C$ can be characterized)

(2) The same as in the conventional method, the capacity of both the leachate treatment plant and the adjustment dam are calculated within the capacity range in Step (1) from water balance analysis using the daily precipitation series in the last 15 years.

(3) The Landfill Cell Model is used to calculate the predicted peak concentration and load amount.

(4) The possible daily precipitation through the seepage coefficient is calculated from the capacity of the leachate treatment plant, which was calculated in Step (2). Then, the quantity of supplied water is calculated by subtracting the daily precipitation that was set in the landfill model for this amount.

(5) The range of the predicted peak concentration is calculated, which was considered to represent the quantity of supplied water.

(6) The optimum capacity of the leachate treatment plant, that of the adjustment dam, and the quality of planned raw water are calculated through Step (2) and Step (5).

\subsubsection{The calculation method for characterizing the planned} raw water quality in closed type (Kazuo et al., 2018)

Figure 8 shows the flow for designing a leachate treatment plant (the capacity of the leachate treatment plant, the capacity of the adjustment dam, and the quality of planned raw water).

(1) The Landfill Cell Model was used to calculate the predicted peak concentration and load amount.

(2) The capacity range of the leachate treatment plant was set using the same method as in [2.1.2 (1)].

(3) The daily leachate amount was calculated from the volume of water for sprinkling according to the liquid: solid ratio.

(4) According to the concentration of $\mathrm{Cl}^{-}$predicted in Step (1), the target $\mathrm{Cl}^{-}$concentration can be set and the dilution amount can be calculated.

(5) The daily amount of leachate can be calculated by the sum of the amounts in Step (3) and Step (4), and the total level should be less than or equal to the amount in Step (2).
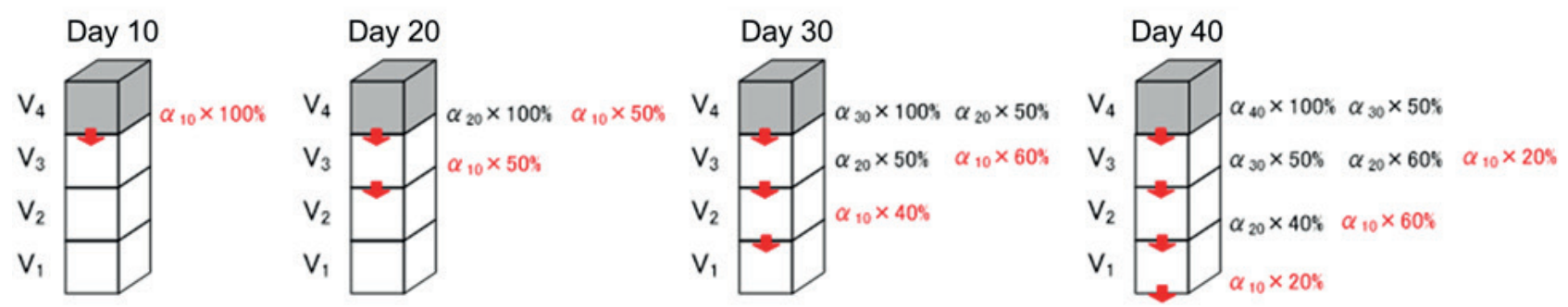

FIGURE 6: The migration concept of $\mathrm{Cl}^{-}$in leachate of Landfill Cell Model. 
The capacity of leachate treatment plant

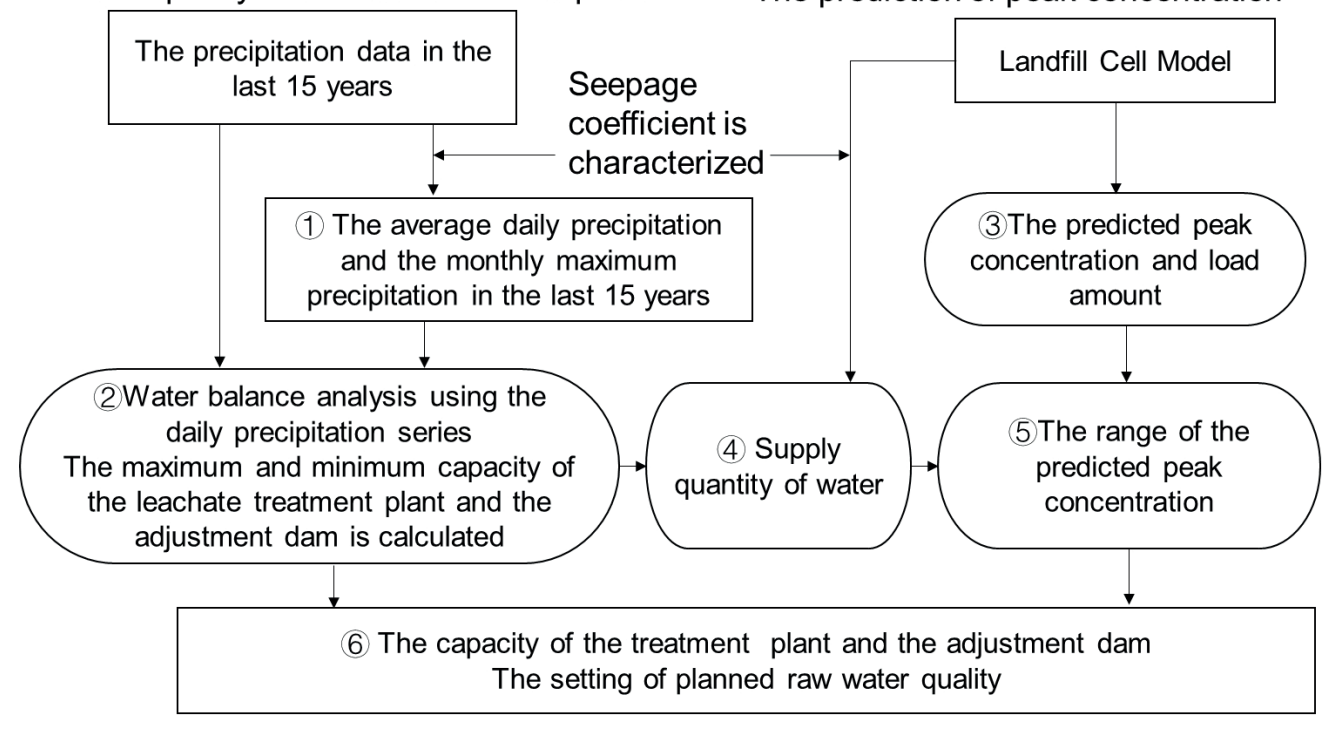

FIGURE 7: The flow for designing a leachate treatment plant.

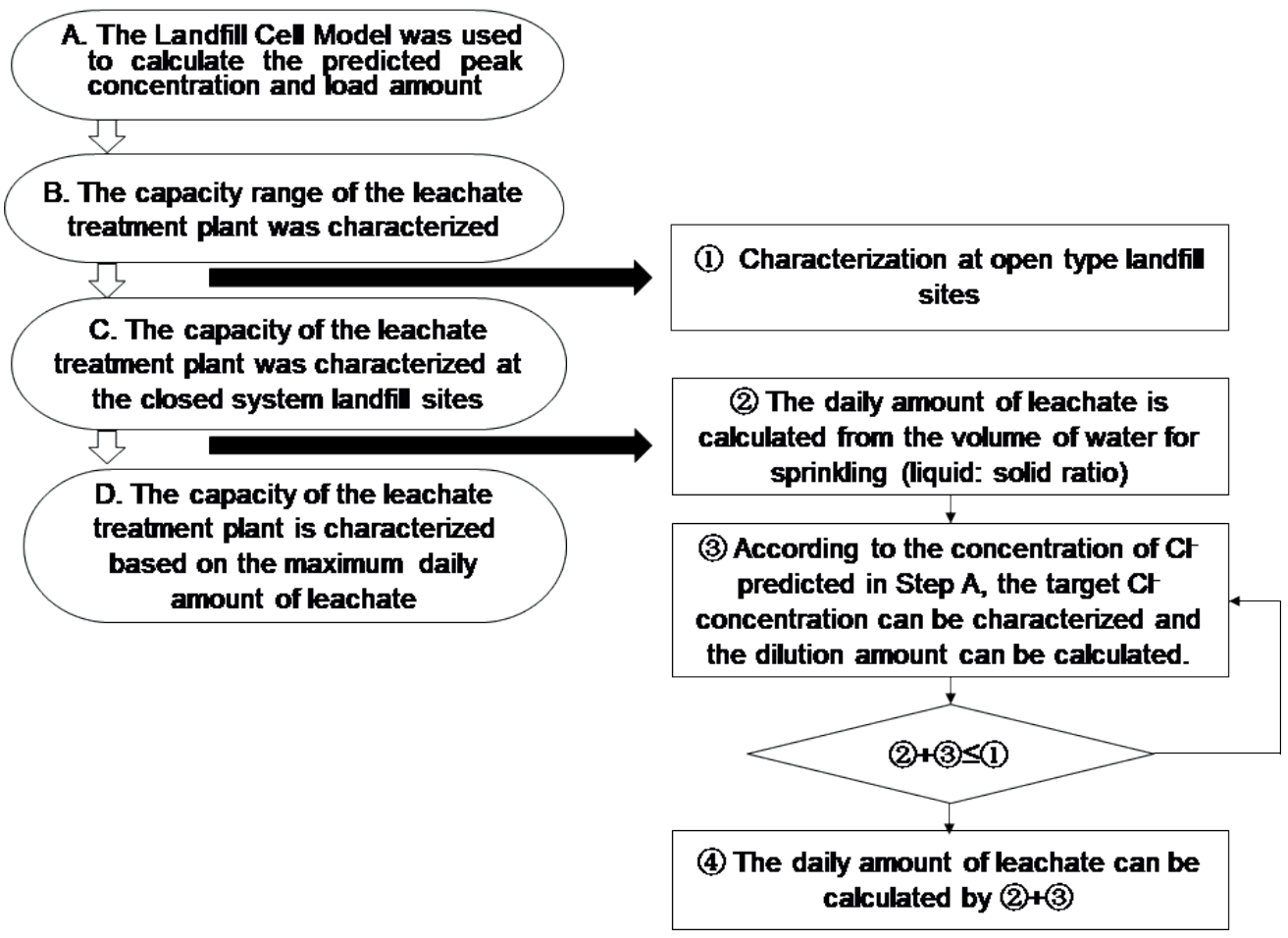

FIGURE 8: The flow for designing a leachate treatment plant.

\subsection{Case study}

\subsubsection{The conditions in the case study}

The case study in this research focused on a treatment plant for a population of 100,000 people, with a capacity of municipal solid waste (MSW) landfill sites of nearly 90,000 $\mathrm{m}^{3}$, a landfill area of about $9,000 \mathrm{~m}^{2}$, a landfill height of 10 $\mathrm{m}$, a landfill duration of 15 years, and incineration residues with $\mathrm{Cl}$ content of $67 \mathrm{~g} / \mathrm{kg}$ (bottom ash: flying ash ratio of 7:3). The one-cell landfill duration of the Landfill Cell Model was set to 10 days (landfill capacity $\sim 160 \mathrm{~m}^{3}$ ).
The capacity of the leachate treatment plant was examined using the past meteorological data of F city. In the last 15 years (2002-2016), the mean annual precipitation was $1,702 \mathrm{~mm}(4.7 \mathrm{~mm} /$ day), the maximum monthly precipitation was $620 \mathrm{~mm}$ (20 mm/day) in July 2009, the landfill area was $A 1=4,500 \mathrm{~m}^{2}$ in the process of the landfilling and $A 2=4,500 \mathrm{~m}^{2}$ in the case of the completed landfill, the seepage coefficient is 0.63 during the duration of landfilling, and will be 0.38 when the landfill is completed. The minimum capacity of the leachate treatment plant is $20 \mathrm{~m}^{3} /$ day and 
its maximum capacity is $90 \mathrm{~m}^{3} /$ day (Sotaro, 2017). This investigation was carried out within this capacity range. The formula for calculating $Q$ is as follows: $Q=(1 / 1000) \times I \times$ $(\mathrm{C} 1 \times A 1+C 2 \times A 2)$.

\subsubsection{Open type (Kazuo et al., 2016 and 2017b)}

The peak concentration of $\mathrm{Cl}^{-}$in leachate and the load amount of $\mathrm{Cl}$ were set by using the method in [2.1.1]. The results as shown in Figure 9 indicate that the concentration fluctuates drastically at the initial stage of the landfill, the peak concentration of $\mathrm{Cl}^{-}$is about $24,863 \mathrm{mg} / \mathrm{L}$, and the load amount of $\mathrm{Cl}$ increases to about $7,640 \mathrm{~kg} / 10$ days when the volume of water for sprinkling is $107,520 \mathrm{~m}^{3}$.

Then, the capacity of the leachate treatment plant is set. As mentioned in [2.2.1], the minimum capacity of the leachate treatment plant (Qop) is $20 \mathrm{~m}^{3} /$ day and its maximum capacity is $90 \mathrm{~m}^{3} /$ day. As a result, the target peak concentration of $\mathrm{Cl}^{-}$is below $10,000 \mathrm{mg} / \mathrm{L}$; dilution water was added to the leachate treatment plant, and the peak concentration of $\mathrm{Cl}^{-}$was adjusted. When the daily precipitation is $38 \mathrm{~m}^{3}$, the amount of dilution water is $40 \mathrm{~m}^{3}$ and the capacity of the leachate treatment plant is $65 \mathrm{~m}^{3} /$ day (Table 1).

The desalination treatment installation determines the capacity of the membrane surface area based on the load amount obtained from the product of the water quantity and the water quality. Therefore, finding the peak load amount and using the maximum load amount to determine the equipment capacity makes it economical. In other words, even if the peak value of water quality is high, if the amount of load at this time is smaller than the maximum value, stable processing can be performed.

For this reason, the quality of $\mathrm{Cl}^{-}$planned raw water is set from the maximum load amount. However, under these conditions, as the landfill method affects a lot, it is necessary to connect the maximum load amount with the landfill method. Besides, since unpredictable situations often occur in actual operations, it is important to have a margin that allows a response to such situations by changing the landfill method used.

\subsubsection{Closed type (Kazuo et al., 2018)}

Based on the method in [2.1.1], the peak concentration of $\mathrm{Cl}^{-}$and the load amount of $\mathrm{Cl}$ in leachate were set. In this case, the liquid: solid ratio used for setting the volume of

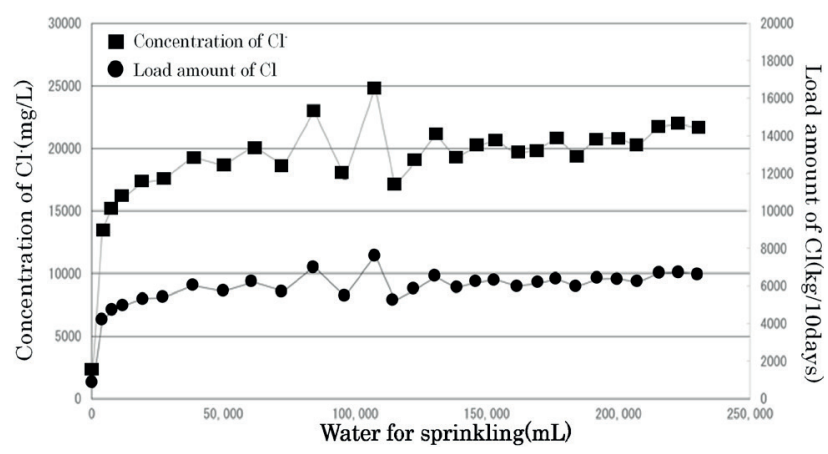

FIGURE 9: The daily changes of the peak concentration of $\mathrm{Cl}^{-}$and load amount of Cl. water for sprinkling is 3:1 (advanced treatment).

As shown in Figure 10, the predicted concentration of $\mathrm{Cl}^{-}$peaks at the initial stage of the landfill, reaching about $101,200 \mathrm{mg} / \mathrm{L}$. The load amount of $\mathrm{Cl}$ becomes the maximum at the end of the landfill, at 2,260 kg/day. At that time, the volume of water for sprinkling is about $137,670 \mathrm{~m}^{3}$ and the total liquid: solid ratio is $1.5: 1$. Besides, 11,540 days (about 31.6 years) after the end of the landfill, the predicted concentration of $\mathrm{Cl}^{-}$is below $1,000 \mathrm{mg} / \mathrm{L}$, the volume of water for sprinkling is about $424,090 \mathrm{~m}^{3}$, and the total liquid: solid ratio is $4.8: 1$. Then, the setting of the volume of water for sprinkling and the quality of $\mathrm{Cl}^{-}$planned raw water is made.

Regarding the volume of water for sprinkling, the liquid: solid ratio is increased to 3:1 (desalination treatment); in this setting, the liquid: solid ratio is $1.5: 1$ at the end of the landfill. In this study, the quality of $\mathrm{Cl}^{-}$planned raw water and the capacity of the leachate treatment plant in closedsystem landfill sites are set, and we estimate the capacity of leachate treatment plant at first. We used the result of setting the capacity of the leachate treatment plant in the case of the open type in [2.2.1]. The minimum capacity of leachate treatment plant is $20 \mathrm{~m}^{3} /$ day, while the maximum value is $90 \mathrm{~m}^{3} /$ day. Our study was conducted within this range. Besides, in the case of setting the volume of water for sprinkling, when the liquid: solid ratio was increased to 3:1 (desalination treatment), the predicted peak concentration of $\mathrm{Cl}^{-}$is $101,200 \mathrm{mg} / \mathrm{L}$ at the initial stage of the landfill. To reduce the burden on the leachate treatment plant, dilution water was added to reduce the concentration of $\mathrm{Cl}^{-}$. Regarding the amount of dilution water to be added, we should make sure that the capacity of the leachate treatment plant is within the range of $20-90 \mathrm{~m}^{3} /$ day. Considering the volume of dilution water under the above conditions, the upper limit for the reduction of $\mathrm{Cl}^{-}$concentration is $26,000 \mathrm{mg} / \mathrm{L}$. However, when the value is above 26,000 $\mathrm{mg} / \mathrm{L}$, the volume of dilution water to be added is set to below $49 \mathrm{~m}^{3} /$ day in the leachate treatment plant. The result is shown in Figure 11. In the case of the volume of dilution water, the maximum value is $49 \mathrm{~m}^{3} /$ day. At the same time, the volume of water for sprinkling is $137,665 \mathrm{~m}^{3}$. Then, when the volume of water for sprinkling is $325,720 \mathrm{~m}^{3}$, the volume of dilution water gradually decreases to $0 \mathrm{~m}^{3}$ /day. Therefore, when the capacity of a leachate treatment plant, which is the sum of the amount of leachate and dilution

TABLE 1: The capacity of the leachate treatment plant.

\begin{tabular}{l|c|c}
\hline Items & UM & Values \\
\hline The predicted peak concentration of $\mathrm{Cl}^{-}$ & $\mathrm{mg} / \mathrm{L}$ & 24,863 \\
\hline The predicted load ammount & $\mathrm{Kg}$ & 7,638 \\
\hline Daily precipitation of Landfill Cell Model & $\mathrm{m}^{3}$ & 38 \\
\hline The target peak concentration of $\mathrm{Cl}^{-}$ & $\mathrm{mg} / \mathrm{L}$ & 10,000 \\
\hline The supply quantity of water & $\mathrm{m}^{3}$ & 40 \\
\hline The peak concentration of Cl- after diluition & $\mathrm{mg} / \mathrm{L}$ & 9,742 \\
\hline Possible ammount of precipitation & $\mathrm{m}^{3}$ & 78,40 \\
\hline Seepage coefficient & $\mathrm{C}$ & 0.8 \\
\hline The capacity of leachate treatment & $\mathrm{m}^{3} / \mathrm{day}$ & 63 \\
\hline
\end{tabular}




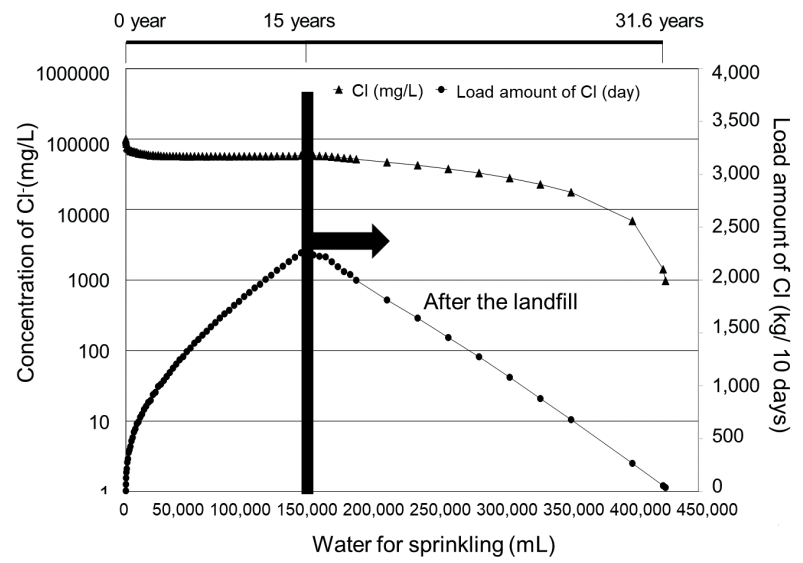

\begin{tabular}{|c|c|c|c|}
\hline \multicolumn{2}{|l|}{ Items } & UM & Values \\
\hline \multicolumn{2}{|c|}{$\begin{array}{l}\text { The maximum predicted value of } \mathrm{Cl}^{-} \\
\text {concentration }\end{array}$} & $\mathrm{mg} / \mathrm{L}$ & $\sim 101,200$ \\
\hline \multirow{3}{*}{$\begin{array}{l}\text { The maximum load } \\
\text { amount of } \mathrm{Cl}\end{array}$} & After the landfill & $\mathrm{Kg} /$ day & $\sim 2,260$ \\
\hline & $\begin{array}{l}\text { The volume of water for } \\
\text { sprinkling }\end{array}$ & $\mathrm{m}^{3}$ & $\sim 137,670$ \\
\hline & The liquid: solid ratio & & $1.5: 1$ \\
\hline \multirow{3}{*}{$\begin{array}{l}\text { The predicted } \\
\text { concentration of } \mathrm{Cl}^{-} \\
\text {below } 1,000 \mathrm{mg} / \mathrm{L}\end{array}$} & After the landfill & $\mathrm{Kg} /$ day & $11,540(\sim 31.6)$ \\
\hline & $\begin{array}{l}\text { The volume of water for } \\
\text { sprinkling }\end{array}$ & $\mathrm{m}^{3}$ & $\sim 424,090$ \\
\hline & The liquid: solid ratio & & $4.8: 1$ \\
\hline
\end{tabular}

FIGURE 10: The predicted peak concentration of $\mathrm{Cl}^{-}$and the load amount of $\mathrm{Cl}$ (liquid:solid ratio: 3:1).

water, reaches $90 \mathrm{~m}^{3} /$ day, the quality of $\mathrm{Cl}^{-}$planned raw water is $26,000 \mathrm{mg} / \mathrm{L}$.

\section{CONCLUSIONS}

The results of this study can be summarized as follows:

(1) When designing MSW landfill sites, it is possible to estimate the peak concentration of $\mathrm{Cl}^{-}$and make a prediction of the quality of raw water regarding its $\mathrm{Cl}^{-}$concentration through the $\mathrm{Cl}$ content in landfill incineration residues and landfill methods.

(2) When the predicted peak concentration of $\mathrm{Cl}^{-}$is generated, it is possible to reduce the peak concentration by adjusting the volume of dilution water at the dilution zone and leachate treatment plant in the case of open type or adjusting the volume of water for sprinkling and dilution in the case of closed type.

(3) In the design of closed-type leachate treatment plants, referring to the peak concentration of $\mathrm{Cl}^{-}$and the load amount of $\mathrm{Cl}$ that is predicted by the Landfill Cell Model and the capacity of open-type leachate treatment plants, it is possible to calculate the volume of dilution

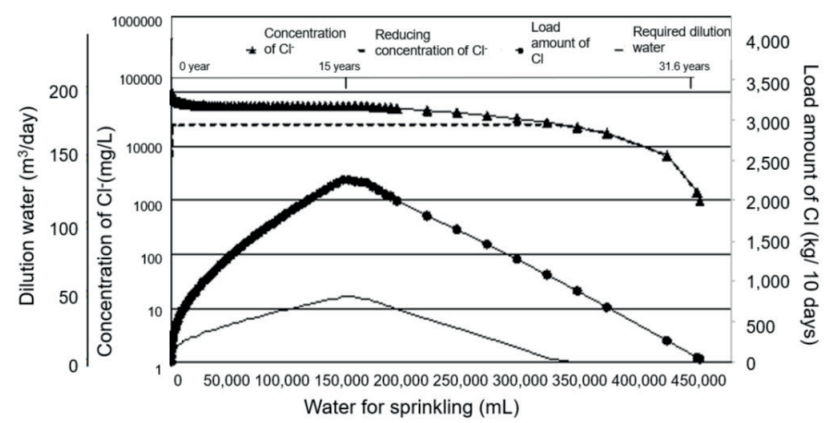

\begin{tabular}{|l|c|c|}
\hline Items & UM & Values \\
\hline Peak concentration (at the initial stage of the landfill) & $\mathrm{mg} / \mathrm{L}$ & 101,200 \\
\hline The maximun load ammount & $\mathrm{Kg} /$ day & 2260 \\
\hline The reduction of peak concentration & $\mathrm{mg} / \mathrm{L}$ & $\begin{array}{c}\text { set below } \\
26,000\end{array}$ \\
\hline The maximun volume of dilution water & $\mathrm{m}^{3} /$ day & 49 \\
\hline The capacity of leachate treatment plant & $\mathrm{m}^{3} /$ day & 90 \\
\hline
\end{tabular}

FIGURE 11: The amount of dilution water and the reduction of predicted peak concentration of $\mathrm{Cl}^{-}$.

water to reduce the concentration of $\mathrm{Cl}^{-}$. As a result, the optimal quality of $\mathrm{Cl}^{-}$planned raw water and the optimal capacity of the leachate treatment plant can be set.

(4) By using the Landfill Cell Model in the open type, it is possible to identify an appropriate landfill method that can achieve stabilization at an early stage.

(5) By using the Landfill Cell Model in the closed type, it is possible to identify an appropriate landfill method, adjust the volume of water for sprinkling, and reduce the $\mathrm{Cl}^{-}$concentration to achieve early stabilization.

\section{REFERENCES}

Japan Waste Management Association (2010). Plan, design and management guidelines for the improvement of MSW landfill sites (2010 revised edition), p.364, pp.417-438.

Kazuo, T et al. (2016). A study on the development of the predictive method of $\mathrm{Cl}^{-}$concentration in leachate. Research presentation in the 27th Material Cycles and Waste Management Conference, pp.431-432.

Kazuo, T et al. (2017a). A study on the development of a predictive method of $\mathrm{Cl}^{-}$concentration in leachate. Japan Waste Management Association and Research, 70(399). pp.101-107.

Kazuo, T et al. (2017b). The development of leachate desalination design method using Landfill Cell Model. Research presentation in the 28th Material Cycles and Waste Management Conference, pp.371-372.

Kazuo, T et al. (2018). The development of leachate desalination process design method of closed system landfill sites using Landfill Cell Model. Proceedings of 39th Japan Waste Management Association and Research, pp.124-126.

Sotaro, H. (2017). Technology for final disposal-waste management and technology for final disposal (No. 21). The City and the Waste, 47(10), pp.45-51. 